\title{
Determination of the oxidizing ability of HTSC materials containing two elements with a variable degree of oxidation
}

\author{
R P PANTALER, N B LEBED and A B BLANK \\ Institute for Single Crystals, Lenin av. 60, Kharkov 310 141, USSR
}

\begin{abstract}
The presence of mixed valence states of elements is supposed to be a common characteristic feature of the high- $T_{c}$ superconductors, based on copper oxides. Methods have been suggested for the determination of $\mathrm{Cu}(\mathrm{III})$ in the $\mathrm{Y}-\mathrm{Ba}-\mathrm{Cu}-\mathrm{O}$ ceramics and separate determination of two oxidants: $\mathrm{Bi}(\mathrm{V})$ and $\mathrm{Cu}(\mathrm{III}), \mathrm{Tl}(\mathrm{III})$ and $\mathrm{Cu}(\mathrm{III})$ in the corresponding materials. Compounds of $\mathrm{Bi}(\mathrm{V})$ oxidize in the ions of $\mathrm{Mn}(\mathrm{II})$ to $\mathrm{MnO}_{4}^{-}$in the acidic medium. Active oxygen, bound to $\mathrm{Cu}(\mathrm{III})$ is isolated, not oxidizing $\mathrm{Mn}(\mathrm{II})$. $\mathrm{MnO}_{4}^{-}$is titrated then with a solution of $\mathrm{Fe}$ (II) sulphate. For the determination of Tl(III) the sample is dissolved in the acid, $\mathrm{Cu}$ (III) is reduced to $\mathrm{Cu}(\mathrm{II})$ and $\mathrm{Tl}(\mathrm{III})$ is titrated with the hydroquinone soiution. The compounds of $\mathrm{Bi}(\mathrm{V}), \mathrm{Tl}(\mathrm{III})$ and $\mathrm{Cu}(\mathrm{III})$, having high oxidation-reduction potentials can oxidize the complex Co(II)-EDTA to Co(III)-EDTA. The colour intensity of the latter is proportional to the content of $\mathrm{Cu}$ (III) or to the sum of $\mathrm{Bi}(\mathrm{V})$ and $\mathrm{Cu}$ (III) or $\mathrm{Tl}$ (III) and $\mathrm{Cu}$ (III). The content of $\mathrm{Cu}(\mathrm{III})$ in $\mathrm{Bi}$ - and Tl-containing materials is determined by the difference.
\end{abstract}

Keywords. Oxidizing ability; valence states of elements; titrimetry; spectrophotometry.

\section{Introduction}

Electrical and magnetic properties of HTSC materials depend, to a great extent, on the oxygen content in them. The correlation between the transition temperature $T$ and the oxygen deficiency $y$ has be $\mathrm{n}$ found for all known oxide copper-containing superconductors. It is shown for example that at $y=0$ for the system $\mathrm{YBa}_{2} \mathrm{Cu}_{3} \mathrm{O}_{7-y}$ $T_{c}$ is maximal $(92 \mathrm{~K})$; with increase of $y, T_{c}$ lowers and at $y=0.6$ it is $22 \mathrm{~K}$ (Raveau et al 1988).

For the HTSC ceramics $\mathrm{Tl}_{2} \mathrm{Ba}_{2} \mathrm{Ca}_{2} \mathrm{Cu}_{2} \mathrm{O}_{x} T_{c}$ is $117 \mathrm{~K}$ at $y=0$ and $99 \mathrm{~K}$ at $y=0.36$ (Schilling et al 1988). The dependence between the superstoichiometric oxygen and $T_{\mathrm{c}}$ for the system $\mathrm{Bi}-\mathrm{Ca}-\mathrm{Sr}-\mathrm{Cu}-\mathrm{O}$ has also been established (Bohaček et al 1988).

It is generally recognized that the oxygen content in HTSC compounds is essentially higher than that which corresponds to the usual valence states for the elements of the composition. Thus, in $\mathrm{YBa}_{2} \mathrm{Cu}_{3} \mathrm{O}_{x}$ high- $T_{c}$ superconductivity appears only at $y>6.5$. The problem of copper, bismuth, thallium and oxygen states has been discussed elsewhere. Some authors consider cipper to be in a mixed valence state: +2 and +3. The data of X-ray electron spectroscopy (Boyce et al 1988; Jaeger 1989; Dobrotvorskaya et al 1988), X-ray absorption spectroscopy (Maeda et al 1987; Lengeler et al 1988) and other methods give evidence in favour of this assumption. According to the other model the electric neutrality of the compound $\mathrm{Y}-\mathrm{Ba}-\mathrm{Cu}-\mathrm{O}$ is ensured by the presence of oxygen in an abnormal degree of oxidation -1 , included in the complex $\mathrm{Cu}^{2+}-\mathrm{O}^{-}$(Bianconi et al 1987). Some authors discuss the probability of existence of the complex $\mathrm{Cu}^{2+}-\mathrm{O}^{\circ}-\mathrm{Cu}^{2+}$ (Khomski and Zvezdin 1988) or oxygen dimers $\mathrm{O}_{2}^{2-}$ (Dzyaloshinskii 1989) as well as $\mathrm{Cu}(\mathrm{I})$ (Sarma and Rao 1988).

Results of the physical methods of investigation do not allow us to solve the problem 
of the valence states of $\mathrm{Cu}, \mathrm{Tl}$ and $\mathrm{Bi}$ unambiguously. However, the presence of mixed valence states of elements is probably a common characteristic of the high- $T_{c}$ superconductors based on copper oxides (Torardi et al 1988). Thallium and copper are supposed to be in the form: $\mathrm{Tl}$ (III) and $\mathrm{Tl}(\mathrm{I}), \mathrm{Cu}$ (III) and $\mathrm{Cu}$ (II) (Hewat et al 1988; Kikuchi et al 1989; Krasinkova and Moizhes 1989; Schilling et al 1989), Bi and $\mathrm{Cu}$ - in the form: $\mathrm{Bi}(\mathrm{III})$ and $\mathrm{Bi}(\mathrm{V}), \mathrm{Cu}(\mathrm{III})$ and $\mathrm{Cu}$ (II) (Bohaček et al 1988; Von Schnering et al 1988; Zandberger et al 1988). A number of analytical methods for the determination of labile oxygen (Watanabe et al 1988; Hornig et al 1989) and formal valence state of copper (Harris et al 1987; Novak et al 1989) have been suggested. Tang and co-authors (1988) showed that $\mathrm{Cu}(\mathrm{I})$ is absent in the HTSC ceramics $\mathrm{YBa}_{2} \mathrm{Cu}_{3} \mathrm{O}_{x}$. We have experimentally found the absence of peroxide compounds in $\mathrm{YBa}_{2} \mathrm{Cu}_{3} \mathrm{O}_{x}$ (Pantaler and Lebed 1989).

The most probable supposition is that the high oxidizing ability of the superconducting complex oxides is due to the presence of $\mathrm{Cu}$ (III) or chemically indistinguishable from its complex $\mathrm{Cu}^{2+}-\mathrm{O}^{-}$as well as $\mathrm{Bi}(\mathrm{V})$ and $\mathrm{Tl}(\mathrm{III})$. Due to the supposed availability of two elements in different formal degree of oxidation in $\mathrm{Bi}$ - and Tl-containing materials: $\mathrm{B}(\mathrm{V})$ and $\mathrm{Bi}(\mathrm{III}), \mathrm{Tl}(\mathrm{III})$ and $\mathrm{Tl}(\mathrm{I}), \mathrm{Cu}(\mathrm{III})$ and $\mathrm{Cu}(\mathrm{II})$, the data obtained by some authors on the oxidizing ability of the said HTSC ceramics should not be attributed only to the presence of $\mathrm{Cu}(\mathrm{III})$. When the reactions of iodide and iron(II) are used for the estimation of the oxidizing ability of the HTSC ceramics (Rao et al 1988; Tarascon et al 1988) apart from $\mathrm{Cu}(\mathrm{III})$ or $\mathrm{Cu}^{2+}-\mathrm{O}^{-}$an essential contribution into the spending of the reducer is made by $\mathrm{Bi}(\mathrm{V})$ and $\mathrm{Tl}(\mathrm{III})$. Our method for the determination of $\mathrm{Cu}(\mathrm{i} I I)$ in the $\mathrm{Y}-\mathrm{Ba}-\mathrm{Cu}-\mathrm{O}$ ceramics and separate determination of two oxidizers $\mathrm{Bi}(\mathrm{V})$ and $\mathrm{Cu}(\mathrm{III}), \mathrm{Tl}(\mathrm{III})$ and $\mathrm{Cu}(\mathrm{III})$ is as follows: Compounds of $\mathrm{Bi}(\mathrm{V})$ oxidize the ions $\mathrm{Mn}(\mathrm{II})$ to $\mathrm{Mn}_{4}^{-}$in the acidic medium. Active oxygen, bound with copper, is isolated from the solution without oxidizing $\mathrm{Mn}$ (II). Thus the permanganite formed is titrated with the solution of the More salt and $\mathrm{Bi}(\mathrm{V})$ content is determined. When determining Tl(III), the sample is dissolved in acidic medium; $\mathrm{Cu}$ (III) is reduced to $\mathrm{Cu}$ (II) with release of gaseous oxygen and $\mathrm{Tl}(\mathrm{III})$ ions are titrated with a solution of hydroquinone which is oxidized to $p$-quinone. The compounds $\mathrm{Bi}(\mathrm{V}), \mathrm{Tl}(\mathrm{III})$ and $\mathrm{Cu}(\mathrm{III})$ possessing high oxidizing-reducing potentials, are able to oxidize the complex Co(II) with EDTA with the formation of the complex Co(III) - EDTA, the intensity of colour of which is proportional to the content of $\mathrm{Cu}(\mathrm{III})$ or the sum of $\mathrm{Bi}(\mathrm{V})$ and $\mathrm{Cu}(\mathrm{III})$ or $\mathrm{Tl}(\mathrm{III})$ and $\mathrm{Cu}$ (III). The content of $\mathrm{Cu}$ (III) in the Bi- or Tl-containing materials is determined by the difference on account of the results of the separate determination of $\mathrm{Bi}(\mathrm{V})$ or $\mathrm{Tl}(\mathrm{III})$.

To find the total content of $\mathrm{Bi}, \mathrm{Tl}$ and $\mathrm{Cu}$ as well as the rest cations of the base, $\mathrm{X}$-ray fluorescence and complexometric methods are used.

\section{Determination of $\mathrm{Bi}(\mathrm{V})$}

Ten $\mathrm{ml}$ of the $\mathrm{HNO}_{3}(1: 2)$ solution, $1 \mathrm{ml}$ of that of $\mathrm{MnSO}_{4}$ and $0 \cdot 1 \mathrm{~g}$ of the ground sample are placed into a conical flask. The contents are mixed until a full dissolution of the sample, diluted with water to the volume $50 \mathrm{ml}$ and titrated with $0.005 \mathrm{M}$ solution of $\mathrm{FeSO}_{4}$ the concentration of which is established on the day of application according to the solution of potassium bichromate. At the end of titration some drops 
of $0.1 \%$ solution of the phenylanthranilic acid are added to the analysed solution and then titration is continued till the disappearance of a red-violet colour of the indicator.

\section{Determination of Tl(III)}

$0.02 \ldots 0.05 \mathrm{~g}$ of the sample is placed into a glass of the capacity of $50 \mathrm{ml}$ and dissolved in $1 \mathrm{ml}$ of the concentrated $\mathrm{HNO}_{3}$ while heated. Fifteen $\mathrm{ml}$ of water is added to the obtained solution and titrated potentiometrically with $0.01 \mathrm{~N}$ solution of hydroquinone in the $0.05 \mathrm{M}$ solution of $\mathrm{HNO}_{3}$ using platinum and chlorum-silver electrodes till the jump of the potential. The hydroquinone solution is standardized with reference to potassium bichromate.

\section{Determination of $\mathrm{Cu}$ (III) and total oxidizing ability of bismuth and copper, thallium and copper}

Five $\mathrm{ml}$ of water, $2 \mathrm{ml}$ each of the $0 \cdot 2 \mathrm{M}$ solutions of EDTA and $\mathrm{CoCl}_{2}, 1 \mathrm{ml}$ of the acetate buffer solution with $\mathrm{pH} 4.5$ and $0.05 \ldots 0.06 \mathrm{~g}$ of the sample are placed in a glass with $50 \mathrm{ml}$ capacity having a ground-in stopper. The glass is put into a magnetic mixer, solution with a precipitate is stirred till the sample is fully dissolved $(1 \cdot 5 \ldots 2 \mathrm{hr})$. The solution is then replaced into a measuring flask with a $50 \mathrm{ml}$ capacity added with water till the marker. The optical density of the solution is measured in a $2 \mathrm{~cm}$ cell at $540 \mathrm{~nm}$ with respect to a solution of the checking sample containing the above mentioned reactants.

By calculations, according to calibration plots, constructed with the help of solutions with the known content of $\mathrm{Bi}(\mathrm{V}), \mathrm{Tl}(\mathrm{III})$ and $\mathrm{Cu}(\mathrm{III})$ with allowance for the previously found content of $\mathrm{Bi}(\mathrm{V})$ or $\mathrm{Tl}(\mathrm{III})$ the content of $\mathrm{Cu}(\mathrm{III})$ is determined. $\mathrm{Tl}_{2} \mathrm{O}_{3}$, synthesized and analysed $\mathrm{Bi}_{2} \mathrm{O}_{5}$, pottasium ditelluratecuprate (III) are used as initial compounds for constructing the plots.

Relative standard deviations, when determining $n \times 10^{-5} \mathrm{M} \mathrm{Cu}(\mathrm{III})$ in the ceramics $\mathrm{Y}-\mathrm{Ba}-\mathrm{Cu}-\mathrm{O}$ for $20 \ldots 25$ tests are $0 \cdot 02 \ldots 0 \cdot 03$, in Ti- and Bi-containing materials: $0 \cdot 04 \ldots 0 \cdot 06 ; \mathrm{Bi}(\mathrm{V}): 0 \cdot 02 \ldots 0 \cdot 05, \mathrm{Tl}(\mathrm{III}): 0 \cdot 007 \ldots 0 \cdot 014$.

The results of determination of the formal state of oxidation of $\mathrm{Cu}, \mathrm{Bi}$ and $\mathrm{Tl}$ in some samples of the superconducting ceramics are given in table 1.

Table 1. HTSC ceramics composition. Experimental results.

\begin{tabular}{|c|c|c|}
\hline System & $\begin{array}{l}\text { Components } \\
\text { ratio }\end{array}$ & Composition \\
\hline $\mathrm{Y}-\mathrm{Ba}-\mathrm{Cu}-\mathrm{O}$ & $1: 2: 3$ & $\mathrm{YBa}_{2} \mathrm{Cu}_{2.04}^{\mathrm{II}} \mathrm{Cu}_{0 \cdot 96}^{\mathrm{III}} \mathrm{O}_{6 \cdot 98}$ \\
\hline $\mathrm{Gd}-\mathrm{Ba}-\mathrm{Cu}-\mathrm{O}$ & $1: 2: 3$ & $\mathrm{GdBa}_{2} \mathrm{Cu}_{2.50}^{\mathrm{II}} \mathrm{Cu}_{0.50}^{\mathrm{III}} \mathrm{O}_{6.75}$ \\
\hline \multirow[t]{3}{*}{$\mathrm{Bi}-\mathrm{Sr}-\mathrm{Ca}-\mathrm{Cu}-\mathrm{O}$} & $1: 1: 1: 2$ & $\mathrm{Bi}_{0.88}^{\mathrm{III}} \mathrm{Bi}_{0 \cdot 12}^{\mathrm{V}} \mathrm{SrCaCu}_{1 \cdot 72}^{\mathrm{II}} \mathrm{Cu}_{0.28}^{\mathrm{III}} \mathrm{O}_{5.76}$ \\
\hline & $2: 2: 1: 2$ & $\mathrm{Bi}_{1 \cdot 81}^{\mathrm{III}} \mathrm{Bi}_{0 \cdot 19}^{\mathrm{v}} \mathrm{Sr}_{2} \mathrm{CaCu}_{1 \cdot 66}^{\mathrm{II}} \mathrm{Cu}_{0 \cdot 34}^{\mathrm{III}} \mathrm{O}_{8 \cdot 36}$ \\
\hline & $4: 3: 3: 4$ & $\mathrm{Bi}_{3.75}^{\text {III }} \mathrm{Bi}_{0.25}^{\mathrm{V}} \mathrm{Sr}_{3} \mathrm{Ca}_{3} \mathrm{Cu}_{3.35}^{\text {II }} \mathrm{Cu}_{0.65}^{\text {III }} \mathrm{O}_{16.58}$ \\
\hline \multirow[t]{2}{*}{$\mathrm{Tl}-\mathrm{Ba}-\mathrm{Ca}-\mathrm{Cu}-\mathrm{O}$} & $1: 2: 1 \cdot 94: 2 \cdot 44$ & $\mathrm{Tl}_{0 \cdot 96}^{\mathrm{III}} \mathrm{Tl}_{0 \cdot 04}^{\mathrm{I}} \mathrm{Ba}_{2} \mathrm{Ca}_{1 \cdot 94} \mathrm{Cu}_{1 \cdot 48}^{\mathrm{II}} \mathrm{Cu}_{0 \cdot 96}^{\mathrm{III}} \mathrm{O}_{8 \cdot 32}$ \\
\hline & $0 \cdot 5: 2: 2 \cdot 66: 4$ & $\mathrm{Tl}_{0 \cdot 4}^{\mathrm{III}} \mathrm{Tl}_{1 \cdot 03}^{1} \mathrm{Ba}_{2} \mathrm{Ca}_{2 \cdot 66} \mathrm{Cu}_{3 \cdot 73} \mathrm{Cu}_{0.27}^{\mathrm{III}} \mathrm{O}_{9 \cdot 52}$ \\
\hline
\end{tabular}




\section{References}

Bianconi A et al 1987 Solid State Commun. 631009

Bohacek P et al 1988 Czech. J. Phys. B38 941

Boyce J B et al 1988 Physica C153-155 852

Dobrotvorskaya M B et al 1988 Dopovidi Akad. Nauk. UkrSSR 52

Dzyaloshinski J E 1989 Pisma v ZhTF 49119

Harris D C and Hewston T A 1987 J. Solid State Chem. 69182

Hewat A W et al 1988 Physica C152 438

Hornig H E et al 1989 Physica C158 480

Jaeger H et al 1989 Physica C153-155 852

Kikuchi M ef al 1989 Jpn. J. Appl. Phys. 28 L 382

Khomski D J and Zvezdin A K 1988 Physica C153-155 1319

Krasinkova M V and Moizhes B Ya 1989 Fizika Tverdogo Tela 31270

Lengeler B et al 1988 Physica C153-155 143

Maeda A et al 1987 Jpn. J. Appl. Phys. 26 L1550

Novak J et al 1989 Physica C157 346

Pantaler R P and Lebed' N B 1989 Sverkhprovodimost: Fizika, Khimiya, Tekhnika 217

Rao C N R et al 1988 Physica C156 827

Raveau B C et al 1988 Physica C153-155 3

Sarma D D and Rao C N R 1988 Solid State Commun. 6547

Schilling A et al 1988 Physica C157 144

Von Schnering H G et al 1988 Angew. Chem. 100604

Tang H S et al 1988 Physica C153-155 826

Tarascon J M et al 1988 Phys. Rev. B37 9382

Torardi C C et al 1988 Phys. Rev. B38 225

Watanabe T et al 1988 Jpn J. Appl. Phys. 27 L1245

Zandberger H W et al 1988 Physica C156 325 